\title{
The Use of Slang among Teenagers in Pidie
}

\author{
Junaidi $^{1^{*}}$, Asriani $^{2}$, Nurul Azmi $^{3}$, Mujiburrahman $^{4}$, Vera Wardani $^{5}$, Nuraiza $^{6}$ \\ ${ }^{1,2,3,4}$ Faculty of Teacher Training and Educational Science, Universitas Serambi Mekkah, Aceh, Indonesia \\ ${ }^{5,6}$ Faculty of Teacher Training and Educational Science, Universitas Jabal Ghafur, Sigli, Indonesia \\ *Corresponding Author: Junaidi, junaidiarsyah1@gmail.com
}

\begin{abstract}
This research is field research aiming to describe the use of slang among teenagers in Pidie. The method used was descriptive-analytical. The data came from Acehnese-speaking teenagers from various social environments in Pidie, Aceh. Data collection was carried out using uninvolved conversation, interviews with inducement technique, recording and note-taking techniques. The data were then analyzed using qualitative analysis techniques that consisted of several stages, namely selecting, identifying, classifying, reducing, presenting data, and drawing conclusions. The results showed that teenagers in Pidie use several types of slang: (a) basic word slang, (b) affix, (c) reduplicated slang, (d) abbreviated slang, (e) slang of crosses, (f) reversal, (g) slang from foreign languages, (h) slang resembling a foreign language, (i) euphemism slang, (j) dysphemism slang, ( $k$ ) code-mixing slang, (l) pun slang, and (m) crossbred slang.
\end{abstract}

Keywords: slang language, slang use, forms of slang, teenagers.

\section{Introduction}

Indonesia is a country with various ethnic groups, and every ethnic group has a language that is different from others. Speech differences, such as dialects, also exist among ethnic groups. This shows that Indonesia is a country with linguistic wealth.

A province in Indonesia with a variety of regional languages is Aceh. The regional languages spoken here are the Acehnese language, Gayo language, Alas language, Tamiang language, Aneuk Jamèe language, Kluet language, Singkil language, Simeulue language, and Haloban language (Wildan, 2010). The Acehnese language, which is the main focus of this study, is spoken with different dialects across the Aceh region, including the dialect of Pidie. Pidie is a district in Aceh which is located approximately $120 \mathrm{~km}$ from the capital city of Aceh, namely Banda Aceh. In Pidie, Acehnese is generally used as the main language (B-1) while Indonesian is used as the second language (B-2).

In speaking, the people of Pidie, especially teenagers, use much slang. Slang can be defined as words with certain meanings and phonology created by people from the same social group. Quite often, slang makers are teenagers. A group of teenagers may not understand the meanings slang words created by another group, which may cause misinterpretations.

According to Hilaliyah (in Inderasari, et al., 2010), slang vocabulary can be in the forms of shortened words, natural words with new meanings, newly formed words, reversal of sound systems. with certain meanings and phonology. Common vocabulary may become strange, sound funny, or even have different meanings. To create slang words, long words are commonly shortened through a morphological process or replaced with shorter words.

A large amount of research has investigated the slang use in different regions of Indonesia, such as the research of Rosalina, et al. (2020), Khoirurrohman and Abdan (2020), Heru and Rukiyah (2019), Setiawan (2019), Ulandari (2018), and Anis (2017). However, research on the use of slang among teenagers in Pidie has never been investigated. Therefore, this research thus aims to find out the types of slang used by teenagers in Pidie, Aceh. 


\section{Method}

This research is field research with a qualitative approach. The method used was descriptive-analytical. The data were collected from Acehnese-speaking teenagers in Pidie who come from various social environments. There were several techniques employed to collect the data, namely uninvolved conversation observation, interviews with the inducement technique, recording, and note-taking. In the uninvolved conversation observation, the researchers only acted as an observer. In the interviews, the researchers attempted to induce informants with a conversation topic on slang to obtain prospective data. The note-taking technique was applied to support other tecniques, namely the free-of-conversation technique, interviews, and inducement technique. The researchers also recorded the conversations with the informants. The collected were the forms of slang used by Pidie teenagers in speech.

The data were then analyzed using a qualitative analysis technique supported with an intralingual equivalent analysis technique. A qualitative analysis is a technique that compares lingual elements, both in one language and in several different languages (Mahsun, 2015). Data analysis was carried out in several stages, namely selecting, identifying, classifying, reducing, presenting data and drawing conclusions.

\section{Results And Discussion}

The forms of slang used by the teenagers in Pidie are presented in the following table:

Table 1. Use of Slang Forms

\begin{tabular}{|c|c|c|c|c|c|}
\hline No. & $\begin{array}{c}\text { The } \\
\text { Category of } \\
\text { Slang Form }\end{array}$ & $\begin{array}{l}\text { The Form } \\
\text { after Being } \\
\text { Changed } \\
\text { into Slang }\end{array}$ & $\begin{array}{l}\text { The } \\
\text { Original } \\
\text { Form }\end{array}$ & $\begin{array}{c}\text { The Slang Use in a } \\
\text { Sentence }\end{array}$ & $\begin{array}{l}\text { Translation of the } \\
\text { Sentence }\end{array}$ \\
\hline 1 & Basic Word & tulong & lutong & Ehai tulong! & You monkey! \\
\hline \multirow[t]{2}{*}{2} & \multirow[t]{2}{*}{ Affixation } & taninchoh & tanoh & $\begin{array}{l}\text { Taninchoh blinchang } \\
\text { kaminchoe kincha } \\
\text { geupeugalincha }\end{array}$ & $\begin{array}{l}\text { Our rice field has been } \\
\text { pawned. }\end{array}$ \\
\hline & & rugumogoh & rumoh & $\begin{array}{l}\text { Rugumogoh jigih kaga } \\
\text { tugutogong } \\
\text { bugunogoe. }\end{array}$ & $\begin{array}{l}\text { His house was burnt just } \\
\text { now. }\end{array}$ \\
\hline 3 & Reduplication & 'eh-'oh & meuagam & $\begin{array}{l}\text { Awaknyan jidrop le } \\
\text { ureung gampong, wab } \\
\text { gadoh 'eh-'oh lam } \\
\text { lampo soh. }\end{array}$ & $\begin{array}{l}\text { That couple was caught } \\
\text { by the people because } \\
\text { they were having sex in } \\
\text { the bush. }\end{array}$ \\
\hline \multirow[t]{2}{*}{4} & \multirow[t]{2}{*}{ Abbreviation } & jerman & $\begin{array}{l}\text { jeurat } \\
\text { manyang }\end{array}$ & $\begin{array}{l}\text { Kamoe ban teuka dari } \\
\text { jerman }\end{array}$ & $\begin{array}{l}\text { We have just arrived } \\
\text { from Jeurat Manyang. }\end{array}$ \\
\hline & & $L B S$ & lambeusoe & $\begin{array}{l}\text { Awaknyan jiwoe } u \\
\text { LBS. }\end{array}$ & $\begin{array}{l}\text { They go home to } \\
\text { Lambeusoe. }\end{array}$ \\
\hline 5 & Cross & soh bak & sakboh & $\begin{array}{l}\text { Gadoh soh bak sabee } \\
\text { di rumoh. }\end{array}$ & $\begin{array}{l}\text { Always enjoy having } \\
\text { sex at home. }\end{array}$ \\
\hline 6 & Reversal & piku & kupi & $\begin{array}{l}\text { Moeka jepmeu piku } \\
\text { kab eeduek pangsim } \\
\text { nayn. }\end{array}$ & $\begin{array}{l}\text { We drink coffee at the } \\
\text { shop near intersection. }\end{array}$ \\
\hline 7 & Euphemism & $\begin{array}{l}\text { taloe } \\
\text { nyawong }\end{array}$ & mom & $\begin{array}{l}\text { Hai! Bek kameuayang } \\
\text { bak taloe nyawoeng! }\end{array}$ & $\begin{array}{l}\text { Hey! Don't play with } \\
\text { breast! }\end{array}$ \\
\hline 8 & Desphemism & euntok & bangai & $\begin{array}{l}\text { Hai euntok! Pakon } \\
\text { meunan sabee kah! }\end{array}$ & $\begin{array}{l}\text { Hey stupid! Why are } \\
\text { you always like that? }\end{array}$ \\
\hline 9 & Mixed Code & taik & $e k$ & $\begin{array}{l}\text { Lagee taik jipeubuet } \\
\text { buet. }\end{array}$ & The job is like shit. \\
\hline
\end{tabular}




\begin{tabular}{|c|l|l|l|l|l|}
\hline 10 & $\begin{array}{l}\text { Foreign } \\
\text { Language }\end{array}$ & $\begin{array}{l}\text { back to } \\
\text { know }\end{array}$ & $\begin{array}{l}\text { bek toe } \\
\text { keunoe }\end{array}$ & Hey, back to know! & $\begin{array}{l}\text { Hey, don't come near } \\
\text { here! }\end{array}$ \\
\hline 11 & $\begin{array}{l}\text { Similar to } \\
\text { Loreign }\end{array}$ & $\begin{array}{l}\text { thong } \\
\text { phong } \\
\text { nyang } \\
\text { chueng } \\
\text { nyan }\end{array}$ & $\begin{array}{l}\text { luweu } \\
\text { dalam } \\
\text { meubee } \\
\text { chueng } \\
\text { nyan }\end{array}$ & $\begin{array}{l}\text { Thong phong nyang } \\
\text { chueng nyan ka jipho- } \\
\text { pho. }\end{array}$ & $\begin{array}{l}\text { The } \\
\text { underware } \\
\text { everywhere. }\end{array}$ \\
\hline 12 & Pun Slang & shanghai & sanggeu & $\begin{array}{l}\text { Abdullah jimeukawen } \\
\text { ushanghai }\end{array}$ & $\begin{array}{l}\text { Abdullah and his family } \\
\text { go to Sanggeu Village. }\end{array}$ \\
\hline 13 & Crossbreed & $\begin{array}{l}\text { board } \\
\text { papeun, } \\
\text { chalkgapu }\end{array}$ & $\begin{array}{l}\text { bet } \\
\text { papeun, } \\
\text { cokgapu }\end{array}$ & gapu! & $\begin{array}{l}\text { Lift the board and take } \\
\text { the chalk! }\end{array}$ \\
\hline
\end{tabular}

From Table 1, it can be seen that there are several forms of slang used by teenagers in Pidie, namely:

1) Slang in the form of root words

This type of slang uses basic words. For example, the word tulong is a slang word for the word lutong. These two words are still in the form of root words.

2) Slang in the form of affixation

The slang word in this form means that it has undergone a morphological process in the form of affixation. There are two processes in forming affixation slang. First, the process of inserting the -in infix and phoneme [ch]. For example, the original word tanoh, 'soil', becomes taninchoh. Second, the process of inserting the phoneme $[\mathrm{m}]$ in each slang syllable. For example, the word rumoh 'house', is made into slang rugumogoh.

3) Slang in the form of reduplication

This type of slang is made up by repeating the root word with little modification. Foe example, the word meuagam becomes 'eh-'oh which means 'to have sex'.

4) Slang in the form of Abbreviation

There are two types of abbreviation to produce this slang type. The first is acronym, for example, Jeurat Manyang for the word Jerman. The second one is common abbreviation, for example, $L B S$ for 'Lambeusoe Village'.

5) Slang of crosses

This type of slang is produced by doing the crossover, which is the process of exchanging sounds between one word and another in a phrase. For example, the phrase sak boh which means 'having intercourse' is changed into slang soh bak.

6) Reversal slang

Reversal slang is slang formed by reversing the location of the syllables to another position in each word in the slang. For example, the word kupi 'coffee' is reversed into piku.

7) Euphemistic slang

Kridalaksana (1993, in Junaidi and Wardani, 2019) states that "euphemism is the use of words or forms of word refinement to avoid prohibitions or taboos". The taboo word mom which means 'breasts' in Acehnese, for instance, is softened into taloe nyawoeng ('the rope of life').

8) Dysphemism slang

Dysphemism is generally used by a speaker to express his/her frustration or anger. A word that has undegone dysphemism can sound very rude. An example for dysphemism is the word euntok which is slang for the word bangai used to address useless people. 


\section{9) Code-mixed slang}

Code-mixed slang is produced by mixing one or two languages. In Pidie, code-mixed slang is the hybrid of Acehnese and Indonesian. For example, the word ek 'dirt' is slang for the word taik.

\section{0) Slang from a foreign language}

This type of slange is made to sound like a foreign language, but it originally is still the Acehnese language. The form of the bek toe that keunoe 'don't come too close to here' is changed back to that know which sounds like English.

\section{1) Slang resembles a foreign language}

This slang type sounds like a foreign language, such as Chinese, Japanese, or Indian. For example, the Acehmese phrase luweu dalam meubee chueng nyan ('the underwear smells like urine') sounds like a Chinese phrase, thong phong nyang chueng nyan, after being altered into slang.

\section{2) Pun Slang}

Puns are new words which sound similar to other words in a well-known context, such as the name of a country, the name of a city, and others. For example, sanggeu 'Sanggeu Village' was changed into shanghai 'a city in China'.

\section{3) Crossbreed Slang}

The crossbreed slang is produced by combining two languages that occupy a sentence. Then, the combination of the two languages produces a grammatical unit in the form of a new sentence. For example, the words papeun, chalk gapu is slang from the basic form of Acehnese phrases bet papeun, cok gapu. The process is the word of board (English) briefly reads [bet] 'lift', and in Aceh it means papeun (Acehnese) 'board' which was then combined with the word chlak (English). It sounds like [cok] 'pick it up', and in Acehnese, it means gapu or 'chalk' in English. Thus, the word elements and meanings of board 'papeun', chalk 'gapu' were changed into slang to form the sentence Board papeun, chalk gapu! meaning: 'Lift the board and take the chalk!'

\section{Conclusion}

Based on the findings, it can be concluded teenagers in Pidie use various types of slang to show social relations, look more trendy, beautify the language, maintain the confidentiality of speech, avoid taboo words, refine speech, roughen speech, make jokes, and divert speech. The types are: (a) root words slang, (b) affixation slang, (c) reduplication slang, (d) abbreviation slang, (e) crossing slang, (f) reversal slang, (g) slang in foreign language form, (h) ) resembles a foreign language, (i) euphemism slang, (j) dysphemism slang, (k) code-mixing, (l) pun slang, and (m) crossbreed slang.

\section{References}

Anis, P. T. (2017). Slang Words in Instagram. Electronic Journal of Literature of Sam Ratulangi University, 1(2), 1-15.

Heru, A. \& Rukiyah, S. (2019). The Usage of Slang Language in Campus Environment of PGRI of Palembang University. Proceeding of Education National Seminar Graduate Program of PGRI University Palembang, 66-74.

Inderasari, E., Fadillah, L.R., Tahe, P. (2020). Variasi Bahasa Slang dalam Talkshow "Hitam Putih" Trans7. Journal LOA Indonesian Language Education of State Islamic Religion Institute of Surakarta, 15 (2), 11-22. 
Khoirurrohman, T., \& Abdan, M.R. (2020). The Analysis of Slang Language Variation Usage on Teenagers in Kalimusu Village: Sociolinguistics Study. Semantics Journal, 1(2) $1-11$.

Junaidi, J., \& Wardani, V. (2019). The Context of Taboo Language Use as Ethics Education of Speech in Pidie Community. Journal of Science Porch, 20 (1), 1-17.

Mahsun, M.S. (2015). The Method of Language Research. Jakarta: Raja Grafindo Persada.

Rosalina, R. A., \& Hermandra, H. (2020). The Usage of Slang Language in Social Media Twitter. Tuah Journal, 2 (1), 77-84.

Setiawan, H. (2019). The Slang Language in Street Food Court in Ponorogo Regency. Jurnal Madah: Jurnal Bahasa dan Sastra, 10 (1), 137-148.

Ulandari, M. (2018). Slang Language in Hallyu Wave Community. Journal of Sociolinguistics, 1(1), 1-10.

Wildan. (2010). The Grammar of Aceh Language. Banda Aceh: Geuci. 